\title{
A Review of Virtual Reality Applications in an Educational Domain
}

\author{
https://doi.org/10.3991/ijim.v15i22.25003 \\ Ghaliya Al Farsi ${ }^{1,2(凶)}$, Azmi bin Mohd. Yusof ${ }^{1}$, Awanis Romli³ $^{3}$ Ragad M Tawafak ${ }^{2}$, \\ Sohail Iqbal Malik ${ }^{2}$, Jasiya Jabbar ${ }^{2}$, Mohd Ezanee Bin Rsuli ${ }^{1}$ \\ ${ }^{1}$ Universiti Tenaga Nasional, Kajang, Malaysia \\ ${ }^{2}$ Al Buraimi University College, Al Buraimi, Oman \\ ${ }^{3}$ University Malaysia Pahang, Gambang, Malaysia \\ galfarsi@buc.edu.om
}

\begin{abstract}
The use of virtual reality (VR) applications has grown tremendously in recent years. This paper focuses on the review of existing virtual reality applications in higher educational institutions. The VR applications are still not widely used although it helps students learn and enhances their performance. Moreover, some factors that lead to the limited use of virtual reality are lack of communication, delay in technology development, weak acquisition of knowledge, etc. This paper provides a comprehensive overview of virtual reality applications in educational institutions. The reviewed articles are taken from databases such as Science Direct, Ebscohost, and Scopus. Furthermore, the reviewed eighteen articles are published between 2016 and 2021. The study analyzed the reviewed articles based on different factors such as fields, purpose, targets, methods, citations, factors, and limitations. The findings revealed that virtual reality applications could play an essential role in the education domain. The reviewed articles highlighted the significant contribution of virtual reality applications in the education domain and their impact on the students' performance. Moreover, the study revealed the critical factors used in VR environments, such as ease of use, efficiency, interactive environments, effectiveness, and learning environments.
\end{abstract}

Keywords - virtual reality, higher education, learning environment, student performance

\section{Introduction}

A new computing platform is born every 15 years. All are ready to integrate and experience the new coming platforms to fine-tune the future. The most exciting futuristic platform revolves around a vision to create enhanced and immersive experiences. When you wear goggles, you are entering a fully immersive computer-generated environment, a virtual world through which the person can interact with the virtual environment.

Virtual Reality (VR) stands for computer machinery to artificially create real-world properties and scenarios [1]. Virtual reality applications have grown tremendously in almost all domains and thus have shown a remarkable impact on various sectors 
like learning, teaching, attitude, and community skills [2]. Virtual reality applications are computer applications that allow users to experience 3D sound and visual stimuli. According to $[28,36,14,15,39]$, virtual reality applications enable users to be engrossed in the 3D world, in which they interact with virtual objects and explore the virtual environment [3].

The main scope of this research work is the educational domain. The characteristics of VR hold many applications within primary education to create new opportunities, increase participation, and enhance student learning in higher educational institutions [4]. The main goal of this research work is to highlight the importance of using VR in higher education institutions to increase the level of student's intrinsic motivation, participation, understanding, and confidence in learning $[6,1]$. Thus, the recent trends of VR application in the field of education have had a significant influence, which has become a means to enable the student to acquire information, thus improving the learning process.

The students are not fond of just the traditional mode of teaching and learning methods alone. The environment has to be enriched with the efficient utilization of technology. To develop, succeed, and utilize this technology and upgrade the quality of education, there is a need to activate the VR usage; besides, proper training must be provided and ensured for both the teachers and the students [1, 2, 7].

New technologies are used to improve learning. The intention of using VR applications as advanced technology is the same as using a 2D program in the initial stages of technology-enhanced learning [4]. VR applications determine the critical factors of education by enhancing the professional development of the teacher's experience, practical simulations, and innovations, and thus the new environment attracts the students and their curiosity and participation $[1,8,9,5]$.

Some tools are related to virtual reality, such as interactive learning environments that enrich ease of use, flexibility, and effectiveness. Besides, various learning activities are offered to the students who take the courses to illustrate how they interact with these events $[9,10]$. Interaction in the learning environment is a vital element and is directly tangible to student performance, same as $[29,2]$. There are collaborative educational environments that involve four elements of the course: teaching, society, teacher assessment, and student evaluation [11]. These factors can be considered as essential factors that lead to the VR application acceptance and use. Constructivism plays a crucial role in the development of educational applications. The employment of virtual reality applications stretches the student's opportunities exclusively to build and enhance knowledge $[9,10]$.

The foremost hindrance in education is the conceptual theories with no simulation, making education neither easy nor understandable. However, Virtual Reality environments enable us to create a model or simulation of reality that makes things familiar and transparent [7, 6]. Besides, VR applications provide three-dimensional (3D) perceptions of the chosen system. Students can thereby learn the principles and theories of the systems in a quicker, effective, and enjoyable way by interacting and traversing the environment created for such a system [11]. This study focus on the following questions:

Q1. What is the purpose of using VR applications in educational projects?

Q2. What is the primary system/model and method used?

Q3. What is the main contribution to knowledge used in VR applications?

Q4. What are the main target groups and the citations of each study? 
This paper is organized into several parts. It begins with a literature review that collects research articles related to VR systems from several open-access databases. A summary of selected publications is represented in a table to determine each study's problems, methods, and knowledge contributions. It is followed by a methodology section that encompasses the processes and impacts of the technologies currently used. Furthermore, results and discussion are included, followed by the conclusion and references.

\section{Literature review}

In this section, a literature review of different studies related to education, engineering, physics, neuropsychology, etc., is presented. Each study was analyzed based on their method of using VR systems. Students all over the world are nowadays more engaged in online learning [11]. VR is riding the development of online education administration systems and amplifies the focus of the educational brand more significantly. This section selected 18 articles related to the study purpose and explained them in Tables 1 and 2 to answer all the questions of this study.

Regarding the respondents' opinion on the position of VR in growing academic cognizance of the brand and as the educational sector developed to use VR as an assistance tool of the learning process, most respondents $(72 \%)$ agreed that VR tools permit more extensive engagement on an implied target market online or with students' interest through e-learning models $[9,12,20]$. [1] presented a VR research related to the use of $3 \mathrm{D}$ in university for student's learning process. The method was to build a model utilizing VR technology to make the learning process easier. The contribution to knowledge statistically shows significant differences; improvement in student achievement in the sample who studied using the 3D lab [10].

In the engineering field, [12] examined the effect of four different methods in the engineering field to assess the students' learning outcomes and feedback. The primary purpose was to examine the VR systems validity among other types of learning. The results compared the scores of the students after each test monitored. The study showed that Virtual reality systems enhance students' achievements in engineering education [12]. The results were incredible, emphasizing that VR applications can be exploited to simplify students learning evolution.

[7] highlights some factors that can impact rehabilitation, such as perceived behavior, self-efficacy, and facilitating conditions $[7,16,20]$. The results revealed the positive influence of these factors to improve the educational process. Furthermore, in the educational process, VR technology's effect on students who face problems in the shift from the information age to the experience age is unbelievable as e-learning modules, hands-on workshops, practical experiences, etc. can be provided [17]. VR is particularly valuable for giving a few openings: expanding understudy commitment; giving constructivist, legitimate encounters to affect understudy character; taking into account new points of view taking and sympathy [18]; furthermore, supporting imagination and the capacity to envision troublesome models. An essential purpose behind using VR as a learning instrument is to meet youthful understudies in a way that they like. [17, 22].

[6] focused on animation usage among universities to increase students engagement. The whole animation model by VR application was utilized to make a simple vision for students. Using unique models of testing and validating data as learning 
theory depending on sampling and questionnaire administration disclosed the influence of effort expectancy and students' performance [18, 21]. Moreover, VR applications have also given a significant opportunity for people with disabilities who do not have the linguistic or physical ability to reach the natural world and experience the educational experiences of the truth. Sometimes a VR application becomes a requisite to make the system tangible and avoid mistakes that may occur in the practice of the existing system, which abolishes or causes impairment, thereby leading to unintended financial losses. Thus, VR applications become mandatory for teaching and providing training, thereby introducing a prototype of the natural system $[12,19]$.

$[8,5]$ said that fast developments in technology had created distance education straightforward. Education is considered a necessity for society, just as Covid 19 has affected the education sector, which led to the transformation of the educational approach entirely via the Internet. The research discusses the importance of distance learning and how to address the challenges of e-learning. The purpose was to improve education and new skills that lead to lifelong learning and know the pros and cons of innovation and development. Furthermore, to solve technical difficulties- download difficulties, software installation problems, sign-in and audio problems by pre-registering for video lectures and there must be a Plan B for teaching. Similarly, courses should be flexible, interactive, and essential training [8, 25, 21, 47].

The e-learning system of Kazakhstan was investigated in [9]. According to the writer, distance education is divided into two important sections: the student and the teacher. The research also stressed the importance of starting e-learning in all regions because of its countless benefits. Some of its benefits are that students can learn and develop themselves independently, encourage them to solve problems themselves, and improve their knowledge. In addition, we should investigate and research different teaching methods to improve education and provide a better understanding for students. We should know that E-learning is an ongoing educational project for long-term use. We should expect more benefits from it in the future too, and we should keep in mind that students are our counters and society $[26,41]$.

[10] aims to see the academic pressures and fears experienced while studying and during exams during the COVID-19 crisis. The survey conducted by university students showed that pressures and fear increase during the final examination period because the grades are higher since the introduction of distance learning for the Covid-19 crisis and the lack of experience in using the study site $[45,42,9]$. In addition, the students who are intense users gain knowledge and perform the tests comfortably. The challenging course material, which has practical, the creation of training and trial programs for students, student account problems, poor signals, etc., are some of the problems faced by the students. All these reasons will affect students' performance and are required to adapt to e-learning [27, 47, 46].

On the other side, [39] determined some difficulties with VR applications, especially in the education process. One of the impediments that the teacher has to face is using these VR applications to motivate them to communicate with the students interestingly to take advantage of educational programs and encourage them to access the virtual experience. Some of the essential elements of virtual reality applications and technology are the manufacturers, the devices manufactured, their quality, the working of the virtual application, how it portraits the system, and how the application improves the level of the students during the educational process [20 27]. 
Table 1 shows the summarized studies of twelve related topics and determines the problem, method, and contributions.

Table 1. Summarized studies

\begin{tabular}{|c|c|c|c|c|}
\hline Ref. & Problem & Purpose & Method & Contribution to Knowledge \\
\hline [1] & $\begin{array}{l}\text { Achievement } \\
\text { of the students } \\
\text { learning }\end{array}$ & $\begin{array}{l}\text { Build a VR technology- } \\
\text { based model to make the } \\
\text { learning process easier }\end{array}$ & $\begin{array}{l}\text { Experimental } \\
\text { method }\end{array}$ & $\begin{array}{l}\text { Metacognitive abilities in } \\
\text { science, significant differences } \\
\text { in student achievement }\end{array}$ \\
\hline [8] & $\begin{array}{l}\text { COVID-19 } \\
\text { affected student } \\
\text { learning methods }\end{array}$ & $\begin{array}{l}\text { Address the challenges } \\
\text { of e-learning }\end{array}$ & Survey & $\begin{array}{l}\text { Teachers and students should } \\
\text { guide on how academic } \\
\text { institutions exploit educational } \\
\text { resources and curricula. }\end{array}$ \\
\hline [29] & $\begin{array}{l}\text { Student's } \\
\text { performance }\end{array}$ & $\begin{array}{l}\text { Address the challenges } \\
\text { of e-learning }\end{array}$ & Survey & $\begin{array}{l}\text { Directly tangent to the student } \\
\text { performance }\end{array}$ \\
\hline [12] & $\begin{array}{l}\text { Achievement of } \\
\text { the students }\end{array}$ & $\begin{array}{l}\text { Examine the VR system } \\
\text { validity among other } \\
\text { types of learning }\end{array}$ & $\begin{array}{l}\text { Experimental } \\
\text { difference } \\
\text { method }\end{array}$ & $\begin{array}{l}\text { A valuable option for clinical } \\
\text { assessment and retraining } \\
\text { restricted major }\end{array}$ \\
\hline$[7]$ & $\begin{array}{l}\text { The analyst } \\
\text { observed behavior } \\
\text { mechanism }\end{array}$ & $\begin{array}{l}\text { Identify developed } \\
\text { technology, most } \\
\text { integrated into } \\
\text { collaborative networks }\end{array}$ & $\begin{array}{l}\text { Many-sided } \\
\text { information } \\
\text { translation } \\
\text { intervention } \\
\end{array}$ & $\begin{array}{l}\text { Increase the interactive exercise } \\
\text { rehabilitation }\end{array}$ \\
\hline [18] & $\begin{array}{l}\text { Struggling in } \\
\text { identifying the } \\
\text { learner's needs in } \\
\text { their lives }\end{array}$ & $\begin{array}{l}\text { Increase imagination } \\
\text { and communication } \\
\text { abilities amongst } \\
\text { learners }\end{array}$ & $\begin{array}{l}\text { Interactive } \\
\text { simulations }\end{array}$ & $\begin{array}{l}\text { VR developed in new } \\
\text { technology to support the } \\
\text { learner's needs }\end{array}$ \\
\hline [5] & Less collaboration & $\begin{array}{l}\text { Determine the factors } \\
\text { of VR }\end{array}$ & $\begin{array}{l}\text { Experimental } \\
\text { method }\end{array}$ & $\begin{array}{l}\text { Underlines the advantages of the } \\
\text { VR application and recognize } \\
\text { the VR innovation abilities } \\
\text { to build the scholarly brand } \\
\text { mindfulness }\end{array}$ \\
\hline$[36]$ & Learners' attitudes & $\begin{array}{l}\text { Increase the imagination } \\
\text { level }\end{array}$ & $\begin{array}{l}\text { Experimental } \\
\text { method }\end{array}$ & $\begin{array}{l}\text { Identify the effects of force } \\
\text { feedback haptic using VR }\end{array}$ \\
\hline [41] & $\begin{array}{l}\text { Perspectives } \\
\text { of receiving } \\
\text { of information } \\
\text { technology } \\
\end{array}$ & $\begin{array}{l}\text { Determine the } \\
\text { suitable factors of VR } \\
\text { applications }\end{array}$ & $\begin{array}{l}\text { Experimental } \\
\text { method }\end{array}$ & $\begin{array}{l}\text { Effectiveness of head-mounted } \\
\text { HMDs in learning }\end{array}$ \\
\hline [39] & $\begin{array}{l}\text { Behavioral } \\
\text { intentions of } \\
\text { using virtual } \\
\text { reality in learning: } \\
\text { perspectives } \\
\text { of acceptance } \\
\text { of information } \\
\text { technology and } \\
\text { learning style }\end{array}$ & $\begin{array}{l}\text { Increase the dimensions } \\
\text { of VR }\end{array}$ & $\begin{array}{l}\text { Experimental } \\
\text { method }\end{array}$ & $\begin{array}{l}\text { Energize head-mounted HMDs } \\
\text { in learning for VR engineers and } \\
\text { instructive foundations }\end{array}$ \\
\hline$[2]$ & $\begin{array}{l}\text { Achievement of } \\
\text { the students }\end{array}$ & $\begin{array}{l}\text { Build a VR technology } \\
\text { model to make the } \\
\text { learning process easier }\end{array}$ & $\begin{array}{l}\text { Experimental } \\
\text { method }\end{array}$ & $\begin{array}{l}\text { Students' creativity and reasons } \\
\text { related to creativity, such as } \\
\text { meditation, flow, and attention, } \\
\text { are amplified. }\end{array}$ \\
\hline
\end{tabular}

(Continued) 
Table 1. Summarized studies (Continued)

\begin{tabular}{|l|l|l|l|l|}
\hline Ref. & \multicolumn{1}{|c|}{ Problem } & \multicolumn{1}{|c|}{ Purpose } & \multicolumn{1}{c|}{ Method } & \multicolumn{1}{c|}{ Contribution to Knowledge } \\
\hline$[6]$ & $\begin{array}{l}\text { Imagination and } \\
\text { communication } \\
\text { abilities amongst } \\
\text { learners }\end{array}$ & $\begin{array}{l}\text { Increase the dimensions } \\
\text { of VR }\end{array}$ & $\begin{array}{l}\text { Sampling and } \\
\text { questionnaire } \\
\text { administration }\end{array}$ & $\begin{array}{l}\text { Increase imagination and } \\
\text { communication abilities } \\
\text { amongst learners }\end{array}$ \\
\hline [40] & $\begin{array}{l}\text { Imagination in } \\
\text { particular creative } \\
\text { methods }\end{array}$ & $\begin{array}{l}\text { Examine the VR } \\
\text { systems validity among } \\
\text { other types of learning }\end{array}$ & $\begin{array}{l}\text { Experimental } \\
\text { method }\end{array}$ & $\begin{array}{l}\text { Increase individual's creative } \\
\text { performance and observer's } \\
\text { attention plus movement state } \\
\text { by a reminder and encouraging } \\
\text { feedback that is based on } \\
\text { electroencephalography }\end{array}$ \\
\hline$[11]$ & $\begin{array}{l}\text { Create (3D) } \\
\text { perceptions into } \\
\text { the organizations }\end{array}$ & $\begin{array}{l}\text { Developing online } \\
\text { studying administration } \\
\text { systems }\end{array}$ & $\begin{array}{l}\text { Experimental } \\
\text { method }\end{array}$ & $\begin{array}{l}\text { Interacting and traversing the } \\
\text { environment created for such a } \\
\text { system }\end{array}$ \\
\hline
\end{tabular}

Table 2. Summarized details of construction stage, target, dimension, field and factors

\begin{tabular}{|c|c|c|c|c|c|}
\hline $\begin{array}{l}\text { Reference/ } \\
\text { Citation }\end{array}$ & Construction Stage & Target & Dimension & Field & Factors \\
\hline [14]/106 & Design & Students & $3 \mathrm{D}, 5 \mathrm{D}, 7 \mathrm{D}$ & Education & Effectiveness \\
\hline$[37] / 15$ & Design & Students & $3 \mathrm{D}$ & Education & Ease of use \\
\hline$[39] / 29$ & Design & Students & $3 \mathrm{D}$ & Education & Efficiency \\
\hline$[11] / 65$ & $\begin{array}{l}\text { Operation \& } \\
\text { management }\end{array}$ & $\begin{array}{l}\text { User } \\
\text { Managers }\end{array}$ & $3 \mathrm{D}, 6 \mathrm{D}$ & Collaboration & $\begin{array}{l}\text { Interactive } \\
\text { environments }\end{array}$ \\
\hline$[28] / 211$ & $\begin{array}{l}\text { Operation \& } \\
\text { management }\end{array}$ & Users & $3 \mathrm{D}, 4 \mathrm{D}, 6 \mathrm{D}$ & Constructed safety & $\begin{array}{l}\text { Learning } \\
\text { environments, }\end{array}$ \\
\hline$[40] / 54$ & Design & Users & $3 \mathrm{D}$ & $\begin{array}{l}\text { Collaboration } \\
\text { Constructed Design }\end{array}$ & $\begin{array}{l}\text { Efficiency, } \\
\text { Effectiveness }\end{array}$ \\
\hline$[1] / 16$ & Review & Students & $3 \mathrm{D}$ & Education & Ease of use \\
\hline$[29] / 97$ & Design & Students & $3 \mathrm{D}, 6 \mathrm{D}$ & Education & Ease of Use \\
\hline$[12] / 176$ & Design & Students & $3 \mathrm{D}, 4 \mathrm{D}$ & Education & $\begin{array}{l}\text { Learning } \\
\text { environment }\end{array}$ \\
\hline$[7] / 47$ & $\begin{array}{l}\text { Operation \& } \\
\text { management }\end{array}$ & Users & $3 \mathrm{D}, 4 \mathrm{D}, 6 \mathrm{D}$ & $\begin{array}{l}\text { Education, } \\
\text { Collaboration }\end{array}$ & $\begin{array}{l}\text { Ease of use, } \\
\text { Effectiveness }\end{array}$ \\
\hline$[18] / 111$ & Design & Students & $3 \mathrm{D}, 4 \mathrm{D}, 6 \mathrm{D}$ & Education & $\begin{array}{l}\text { Interactive } \\
\text { Environment }\end{array}$ \\
\hline$[5] / 4$ & Design & Students & $3 \mathrm{D}, 6 \mathrm{D}$ & Education & Effectiveness \\
\hline$[36] / 20$ & Design & Students & $3 \mathrm{D}, 4 \mathrm{D}$ & Education & Efficiency \\
\hline$[41] / 29$ & $\begin{array}{l}\text { Operation \& } \\
\text { management }\end{array}$ & $\begin{array}{l}\text { User } \\
\text { Managers }\end{array}$ & $3 \mathrm{D}$ & Collaboration & $\begin{array}{l}\text { Interactive } \\
\text { environment, } \\
\text { Effectiveness }\end{array}$ \\
\hline$[14] / 73$ & Design & Students & $3 \mathrm{D}$ & Education & Efficiency \\
\hline$[2] / 16$ & $\begin{array}{l}\text { Operation \& } \\
\text { management }\end{array}$ & Users & $3 \mathrm{D}, 4 \mathrm{D}, 6 \mathrm{D}$ & Collaboration & Ease of use \\
\hline$[6] / 9$ & Design & Students & $3 \mathrm{D}, 4 \mathrm{D}, 6 \mathrm{D}$ & Education & Ease of use \\
\hline$[38] / 22$ & $\begin{array}{l}\text { Operation \& } \\
\text { management }\end{array}$ & $\begin{array}{l}\text { User } \\
\text { Managers }\end{array}$ & $3 \mathrm{D}, 6 \mathrm{D}$ & Collaboration & $\begin{array}{l}\text { Learning } \\
\text { environment }\end{array}$ \\
\hline
\end{tabular}




\section{$3 \quad$ Methodology}

Recent articles available on open-access database system are reviewed, and articles based on virtual reality applications which are effective and shows a significant impact on learning and academic performance are selected in this research work. The Analysis and retrieving procedure was performed using three keywords "VR application," "VR application in Learning," and "VR application in academic Performance." Firstly, virtual reality applications aim at numerous features that help like estimation, study, psychology, medication, and treatment. Secondly, the uses of virtual reality applications in the education and learning fields and their impact on enhancing academic performance. It is a significant factor that the study is limited to articles on educational performance. The studies were checked and filtered based on years of publication and selected papers in a specific period from 2016 to 2021. The search was applied in three databases, namely SCIENCE DIRECT, EBSCOHOST, and SCOPUS, as shown in Table 2. The keywords used in this search engine were virtual reality applications to enhance students' achievement, virtual reality applications to increase academic performance and the virtual environment's effectiveness.

The result of the search included thousands of deference topics of virtual reality. The papers were excluded based on repetition, posters, books, thesis, and magazines. Besides that, the topics related to medicine, physiology, science were omitted and included only the issues associated with virtual reality in the education and learning sectors (see Figure 1). Table 3 shows the available matched articles in open-access databases such as SCIENCE DIRECT, EBSCOHOST, and SCOPUS. The reports are based on the virtual reality applications factor- the total reached articles were 34236 papers. All the selected articles used in the literature review section were used from 2016 to 2021 to use the latest updated topics related to VR. The method used to analyze the articles to find the target, purpose, citation, construction stage, the method used, field, factors, and limitations distributed between the two tables of Table 1 and Table 2, respectively.

Table 3. Open access database

\begin{tabular}{|c|c|c|c|}
\hline Database Name & Field & Years (2016-2021) & Totals \\
\hline \multirow[t]{3}{*}{ SCIENCE DIRECT } & VR applications & 15300 & \multirow{3}{*}{21648} \\
\hline & VR applications in learning & 3499 & \\
\hline & VR applications in academic performance & 2849 & \\
\hline \multirow[t]{3}{*}{ SCOPUS } & VR applications & 9832 & \multirow{3}{*}{10625} \\
\hline & VR applications in learning & 757 & \\
\hline & VR applications in academic performance & 36 & \\
\hline \multirow[t]{3}{*}{ EBSCOhost } & VR applications & 1830 & \multirow{3}{*}{1963} \\
\hline & VR applications in learning & 111 & \\
\hline & VR applications in academic performance & 22 & \\
\hline Total $=34236$ & & & \\
\hline
\end{tabular}


Articles screened from 3 different open access database

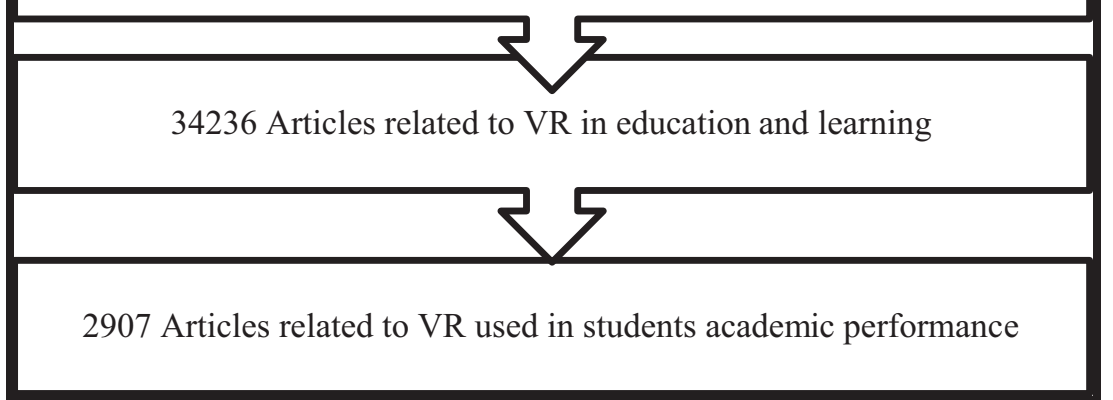

Fig. 1. Extracting relevant publications

\section{$4 \quad$ Result and discussion}

In this small-scale research, we found that the usability of VR applications in higher education institutions increased the academic performance factor. It increased dramatically, evident in each year's increased look-alikes and additional [24]. We found nearly three thousand papers related to academic performance, as shown in Table 3, and used six pieces to discuss virtual reality's importance in the learning area. It focuses on and discusses VR use in learning and the need for new methods and assessments to enhance and increase understanding. For this intention, it is clear that the VR application is critical in any higher educational institution.

The study came out with the core factors used in VR applications. As mentioned in Table 2, the five factors include interactive, learning, efficiency, effectiveness, and ease of use. Table 2 mentioned the field used, dimensions like $3 \mathrm{D}, 4 \mathrm{D}, 5 \mathrm{D}$, and 6D.

The results of the review are:

- Consuming any VR system radically progresses the students' performance.

- An effective VR system development can effectively utilize the information age benefits to those with CNS impairments dysfunction.

- The animation usage behavior of students increased students' innovation.

- Studies also showed students' positive attitudes towards 3DL teaching. Improvements in logical and visual thinking were also detected.

\section{Conclusion}

The conclusion of this review can be comprehended in the following phrase: "There is a lack in the student's academic level in the traditional model of education. The use of virtual reality applications influences the engagement and performance of the learners". 
Virtual reality applications have their place in education and play a vital role and prove their importance from the results of the reviewed articles of this study. There is a broad scope for this topic in research. It will be interesting to see more and more learning systems based on virtual reality in the future. We can also connect virtual phones as well as will be able to create more realistic images and graphics to simulate reality. Virtual reality applications can be used in the educational area and also in day-to-day activities and work environments. The authors recommend 3DL in Omani schools and emphasize the need to conduct more research on different virtual labs in science education at higher education institutions. Furthermore, VR systems are very beneficial to medical students too. The future is virtual reality applications, and its benefits will remain countless and immeasurable.

\section{Acknowledgment}

The authors would like to thank the Ministry of Higher Education for providing financial support under Fundamental Research Grant Scheme (FRGS) No. FRGS/1/2018/ TK10/UMP/02/3 (University reference RDU1903116). Thanks to University Malaysia Pahang for their financial support.

\section{$7 \quad$ References}

[1] Sidani, A., Dinis, F. M., Sanhudo, L., Duarte, J., Baptista, J. S., Martins, J. P., \& Soeiro, A. (2021). Recent Tools and Techniques of BIM-Based Virtual Reality: A Systematic Review. Archives of Computational Methods in Engineering, 28(2), 449-462. https://doi.org/10.1007/ $\underline{\text { s11831-019-09386-0 }}$

[2] Alfarsi, G., Tawafak, R. M., ElDow, A., Malik, S. I., Jabbar, J., Al Sideiri, A., \& Mathew, R. (2021). General View about an Artificial Intelligence Technology in Education Domain. https://doi.org/10.5220/0010304501200127

[3] Tatnall, A. (2019). Editorial for EAIT issue 2, 2019. Education and Information Technologies, 24(2), 953-962. https://doi.org/10.1007/s10639-019-09874-7

[4] Tawafak, R., AlFarsi, G., Jabbar, J., Malik, S. I., Mathew, R., AlSidiri, A., .. \& Romli, A. (2021). Impact of Technologies During COVID-19 Pandemic for Improving Behavior Intention to Use E-learning. https://doi.org/10.3991/ijim.v15i01.17847

[5] Capatina, A., Schin, G. C., \& Rusu, D. (2017). Increasing Academic Brand Awareness through Virtual Reality. Revista De Management Comparat International, 18(2), 171.

[6] Dajani, D., \& Hegleh, A. S. A. (2019). Behavior intention of animation usage among university students. Heliyon, 5(10), e02536. https://doi.org/10.1016/j.heliyon.2019.e02536

[7] Levac, D., Glegg, S. M., Sveistrup, H., Colquhoun, H., Miller, P. A., Finestone, H., ... \& Velikonja, D. (2016). A knowledge translation intervention to enhance clinical application of a virtual reality system in stroke rehabilitation. BMC health services research, 16(1), 1-11. https://doi.org/10.1186/s12913-016-1807-6

[8] Dhawan, S. (2020). Online Learning: A Panacea in the Time of COVID-19 Crisis. Journal of Educational Technology Systems, 49(1), 5-22. https://doi.org/10.1177/0047239520934018

[9] Ali, W. (2020). Online and Remote Learning in Higher Education Institutes: A Necessity in Light of COVID-19 Pandemic. Higher education studies, 10(3), 16-25. https://doi. org $/ 10.5539 /$ hes.v10n3p16 
[10] Moawad, R. A. (2020). Online Learning during the COVID- 19 Pandemic and Academic Stress in University Students. Revista Românească pentru Educaţie Multidimensională, 12(1 Sup2), 100-107. https://doi.org/10.18662/rrem/12.1sup2/252

[11] Edwards, G., Li, H., \& Wang, B. (2015). BIM-based collaborative and interactive design process using computer game engine for general end-users. Visualization in Engineering, 3(1), 1-17. https://doi.org/10.1186/s40327-015-0018-2

[12] Alhalabi, W. (2016). Virtual reality systems enhance students' achievements in engineering education. Behaviour \& Information Technology, 35(11), 919-925. https://doi.org/10.1080/ 0144929X.2016.1212931

[13] Goff, E. E., Mulvey, K. L., Irvin, M. J., \& Hartstone-Rose, A. (2018). Applications of Augmented Reality in Informal Science Learning Sites: a Review. Journal of Science Education and Technology, 27(5), 433-447. https://doi.org/10.1007/s10956-018-9734-4

[14] Jensen, C. G. (2017). Collaboration and Dialogue in Virtual Reality. Journal of Problem Based Learning in Higher Education, 5(1).

[15] Papadakis, S., Vaiopoulou, J., Sifaki, E., Stamovlasis, D., \& Kalogiannakis, M. (2021). Attitudes towards the Use of Educational Robotics: Exploring Pre-Service and In-Service Early Childhood Teacher Profiles. Education Sciences, 11(5), 204. https://doi.org/10.3390/ educsci11050204

[16] Garbe, A., Ogurlu, U., Logan, N., \& Cook, P. (2020). COVID-19 and Remote Learning: Experiences of Parents with Children during the Pandemic. American Journal of Qualitative Research, 4(3), 45-65. https://doi.org/10.29333/ajqr/8471

[17] Khan, T., Johnston, K., \& Ophoff, J. (2019). The Impact of an Augmented Reality Application on Learning Motivation of Students. Advances in Human-Computer Interaction, 2019. https://doi.org/10.1155/2019/7208494

[18] Hu-Au, E., \& Lee, J. J. (2017). Virtual reality in education: a tool for learning in the experience age. International Journal of Innovation in Education, 4(4), 215-226. https://doi. org/10.1504/IJIIE.2017.091481; https://doi.org/10.1504/IJIIE.2017.10012691

[19] Cheng, K. H., \& Tsai, C. C. (2013). Affordances of Augmented Reality in Science Learning: Suggestions for Future Research. Journal of science education and technology, 22(4), 449-462. https://doi.org/10.1007/s10956-012-9405-9

[20] Jabbar, J., Malik, S. I., AlFarsi, G., \& Tawafak, R. M. (2021). The Impact of WhatsApp on Employees in Higher Education. In Recent Advances in Intelligent Systems and Smart Applications (pp. 639-651). Springer, Cham. https://doi.org/10.1007/978-3-030-47411-9 34

[21] Martín-Gutiérrez, J., Mora, C. E., Añorbe-Díaz, B., \& González-Marrero, A. (2017). Virtual Technologies Trends in Education. Eurasia Journal of Mathematics, Science and Technology Education, 13(2), 469-486. https://doi.org/10.12973/eurasia.2017.00626a

[22] Soto, J. B., Ocampo, D. T., Colon, L. B., \& Oropesa, A. V. (2020). Perceptions of immerse me virtual reality platform to improve English communicative skills in higher education.

[23] Khairudin, M., Triatmaja, A. K., Istanto, W. J., \& Azman, M. N. A. (2019). Mobile Virtual Reality to Develop a Virtual Laboratorium for the Subject of Digital Engineering.

[24] Tzagkaraki, E., Papadakis, St., \& Kalogiannakis, M. (2021). Exploring the Use of Educational Robotics in primary school and its possible place in the curricula. In M. Malvezzi, D. Alimisis, \& M. Moro (Eds). Education in \& with Robotics to Foster 21st Century Skills. Proceedings of EDUROBOTICS 2020, Online Conference February 25-26, 2021, 216-229, Switzerland, Cham: Springer. https://doi.org/10.1007/978-3-030-77022-8_19

[25] Tatnall, A. (2020). Correction to: Editorial for EAIT issue 2, 2020. Education and Information Technologies, 25(6), 5901-5910. https://doi.org/10.1007/s10639-020-10360-8; https:// doi.org/10.1007/s10639-020-10180-w

[26] Fernandez, M. (2017). Augmented Virtual Reality: How to Improve Education Systems. Higher Learning Research Communications, 7(1), 1-15. https://doi.org/10.18870/hlrc. v7i1.373 
[27] Vidakis, N., Barianos, A. K., Trampas, A. M., Papadakis, S., Kalogiannakis, M., \& Vassilakis, K. (2019, May). in-Game Raw Data Collection and Visualization in the Context of the "ThimelEdu" Educational Game. In International Conference on Computer Supported Education (pp. 629-646). Springer, Cham. https://doi.org/10.1007/978-3-030-58459-7_30

[28] Wang, P., Wu, P., Wang, J., Chi, H. L., \& Wang, X. (2018). A Critical Review of the Use of Virtual Reality in Construction Engineering Education and Training. International journal of environmental research and public health, 15(6), 1204. https://doi.org/10.3390/ ijerph15061204

[29] Grover, S., Franz, P., Schneider, E., \& Pea, R. (2013). The MOOC as distributed intelligence: Dimensions of a framework \& evaluation of MOOCs.

[30] Tawafak, R. M., Alfarsi, G., \& Jabbar, J. (2021). Innovative Smart Phone Learning System for Graphical Systems within COVID-19 Pandemic. Contemporary Educational Technology, 13(3), ep306. https://doi.org/10.30935/cedtech/10879

[31] Tatnall, A. (2020). Editorial for EAIT issue 2, 2020. Education and Information Technologies, 25(2), 647-657. https://doi.org/10.1007/s10639-020-10135-1

[32] AlFarsi, G., Tawafak, R. M., ElDow, A., Malik, S. I., Jabbar, J., \& Al Sideiri, A. (2021). General View about Games based Learning: Literature Review. https://doi. org/10.5220/0010304801390145

[33] Al Farsi, G., Yusof, A. B. M., Fauzi, W. J. B., Rusli, M. E. B., Malik, S. I., Tawafak, R. M., ... \& Jabbar, J. (2021). The Practicality of Virtual Reality Applications in Education: Limitations and Recommendations. Journal of Hunan University Natural Sciences, 48(7).

[34] Iqbal Malik, S., Mathew, R., Tawafak, R. M., \& Alfarsi, G. (2021). A web-based model to enhance algorithmic thinking for novice programmers. E-Learning and Digital Media, 20427530211026988. https://doi.org/10.1177/20427530211026988

[35] AlFarsi, G., Jabbar, J., Tawafak, R. M., ElDow, A., Malik, S. I., \& Alsideiri, A. (2021). Modern Education and an Artificially Intelligent World. https://doi.org/10.5220/0010304201130119

[36] Ucar, E., Ustunel, H., Civelek, T., \& Umut, I. (2017). Effects of using a force-feedback haptic augmented simulation on the attitudes of the gifted students towards studying chemical bonds in virtual reality environment. Behaviour \& Information Technology, 36(5), 540-547. https://doi.org/10.1080/0144929X.2016.1264483

[37] Tawafak, R. M., Romli, A., Al Sideiri, A., Malik, S. I., \& Jabbar, J. (2021, February). Concepts of e-learning performance on system use outcomes in Omani Universities. In IOP Conference Series: Materials Science and Engineering (Vol. 1088, No. 1, p. 012008). IOP Publishing. https://doi.org/10.1088/1757-899X/1088/1/012008

[38] Vaiopoulou, J., Papadakis, S., Sifaki, E., Stamovlasis, D., \& Kalogiannakis, M. (2021). Parents' Perceptions of Educational Apps Use for Kindergarten Children: Development and Validation of a New Instrument (PEAU-p) and Exploration of Parents' Profiles. Behavioral Sciences, 11(6), 82. https://doi.org/10.3390/bs11060082

[39] Shi, Y., Du, J., Lavy, S., \& Zhao, D. (2016). A Multiuser Shared Virtual Environment for Facility Management. Procedia Engineering, 145, 120-127. https://doi.org/10.1016/j. proeng.2016.04.029

[40] Shen, C. W., \& Ho, J. T. (2020). Technology-enhanced learning in higher Education: A bibliometric analysis with the latent semantic approach. Computers in Human Behavior, 104, 106177. https://doi.org/10.1016/j.chb.2019.106177

[41] Wang, B., Li, H., Rezgui, Y., Bradley, A., \& Ong, H. N. (2014). BIM Based Virtual Environment for Fire Emergency Evacuation. The Scientific World Journal, 2014. https://doi. org $/ 10.1155 / 2014 / 589016$

[42] Wu, T. H., Wu, F., Liang, C. J., Li, Y. F., Tseng, C. M., \& Kang, S. C. (2019). A virtual reality tool for training in global engineering collaboration. Universal Access in the Information Society, 18(2), 243-255. https://doi.org/10.1007/s10209-017-0594-0 
[43] Yang, X. (2019). Accelerated move for AI education in China. ECNU Review of Education, 2(3), 347-352. https://doi.org/10.1177/2096531119878590

[44] Papadakis, S. (2020). Robots and Robotics Kits for Early Childhood and First School Age. International Journal of Interactive Mobile Technologies (iJIM), 14(18), 34-56. https://doi. org/10.3991/ijim.v14i18.16631

[45] Tawafak, R. M., Romli, A., Malik, S. I., Alfarsi, G., \& Jabbar, J. (2021, February). Examining continuous integrating of technology acceptance model with task-technology fit. In IOP Conference Series: Materials Science and Engineering (Vol. 1088, No. 1, p. 012061). IOP Publishing. https://doi.org/10.1088/1757-899X/1088/1/012061

[46] Malik, S. I., Tawafak, R. M., \& Alfarsi, G. (2021). A Model for Enhancing Algorithmic Thinking in Programming Education using PAAM. International Journal of Interactive Mobile Technologies, 16(9). https://doi.org/10.3991/ijim.v15i09.20617

[47] Clustering, A. S. 2019 International Arab Conference on Information Technology (ACIT). Higher Education, 165, 170.

\section{Authors}

Ghaliya AlFarsi She is working in AlBuraimi University College with experience of more than 15 years. Currently, she is a Ph.D. candidate in Malaysia. She published more than 50 papers between Scopus journals and peer-reviewed conferences.

Azmi bin Mohd. Yusof is Assoc. Prof in Computing and Information college. Universiti Tenaga Nasional, Malaysia. His master's degree in Computer Science, Western Michigan University, MI, USA, 1988. BSc in Computer Science, Wichita State University, KS, USA, 1986. Most of his publications are Scopus-indexed. His current research interests include virtual reality, imaging, and visualization.

Awanis BT Romli She is an Associate Professor at University Malaysia Pahang (UMP). She got experience in the e-learning field and more than 80 papers published in a respected Web of Science and Scopus journal.

Ragad M. Tawafak is an Assistant professor in the information technology department at AlBuraimi university college. She works in AlBuraimi University College (BUC) for more than 15 years. She is an expert in e-learning, Virtual reality, and information systems topics. She published more than 73 papers.

Sohail Iqbal Malik Sohail's research interest includes Algorithmic Thinking, Computer Education, Technology in Education, Problem Solving Skills and Mobile Learning.

Jasiya Jabbar She is working at AlBuraimi University College. She published several papers between Scopus journals and peer-reviewed conferences. The area of interest includes e-learning, mobile applications, and artificial intelligence.

Mohd Ezanee Bin Rsuli is Associate Professor in the Computing and Information College, Universiti Tenaga Nasional, Malaysia. Most of his publications are Scopus-indexed. His current research interests include virtual reality, imaging, and visualization.

Article submitted 2021-06-22. Resubmitted 2021-08-17. Final acceptance 2021-08-17. Final version published as submitted by the authors. 